\title{
Photosynthetic productivity of sugar beet depending on periods of sowing and fertilizer system
}

\author{
V. Lyhochvor \\ Sciences \\ Lviv National Agrarian University \\ S. Kostiuchko \\ Institute of Agriculture of the Carpathian region NAAS
}

Corresponding Member of the National Academy of Agrarian Sciences, Doctor of Agricultural

The purpose. To determine influence of periods of sowing and fertilizer system on indexes of photosynthetic activity of plants of sugar beet. Methods. Field, laboratory, registration-weight. The square of leaves, photosynthetic potential, net productivity of photosynthesis were determined according to growth phases. Results. Influence of periods of sowing and fertilizers is determined on the square of leaves, photosynthetic potential, mass of dry matters, and net productivity of photosynthesis. Conclusions. The square of leaves changes a little as a function of periods of sowing, and under the influence of fertilizers it increases in 2 times. Net productivity of photosynthesis is augmented at early periods of sowing (March, 20 - April, 10) and less depends on the level of fertilizing.

Key words: sugar beet, periods of sowing, fertilizer system, indexes of photosynthetic activity.

Introduction. The optimum leaf surface area is one of the main factors for the formation of high yields of root crops with good technological qualities and increased content of sugar. [9] The daily increase yield of sugar beet is determined by the leaf surface area and productivity of photosynthesis, that's why all elements of the technology should be directed to ensure optimal conditions for physiological processes $[2,4,6]$. It is important to ensure a rapid increase of assimilation leaf surface as long as possible and store them in an active state [10].The area of plant leaf depends on the number of functioning leaves and leaf area of each.

Analysis of recent researches and publications. According to A.A.Nychyporovycha [6,7], the optimum area of leaf surface is $40-50$ thousands $\mathrm{m}^{2} / \mathrm{ha}$. Its further increasing is already inefficient, because it significantly reduces the average light of leaves, and thus pure productivity of photosynthesis too. According to other data, the index of leaf surface should not exceed 3.5-4.0 [1]. According to some researchers, the optimum area of leaf surface of sugar beets is within 50-80 thousands $\mathrm{m}^{2}$ [8]. This index reaches maximum on August. [4]. The leaf apparatus in the western districts of sugar beets sowings, especially in conditions of sufficient moisture is preserved for a longer period, even during gathering the ratio of the mass of sugar beet tops to roots is approximately 1 to 1 . During the vegetation period the area of leaf surface reached 34,5-46,6 thousands $\mathrm{m}^{2} /$ ha [3]; 39,8-50,1thousands $\mathrm{m}^{2} / \mathrm{ha}$ [4]. Photosynthetic potential expresses the sum of the daily indices of leaves area according to the vegetation period. According to A.O. Nychyporovycha [7], sowings are considered good when their photosynthetic capacity is 2,2-3,0 million $\mathrm{m}^{2}$ days/ha,average ones $-1,0-1,5$ million $\mathrm{m}^{2}$ days/ha and unsatisfactory ones - for 0,5-0 7 million $\mathrm{m} 2$ days/ha.

Materials and methods. Indices of photosynthetic activity of sugar beets on Carlton hybrid was studied during five sowings terms namely: March 20, April 1, April 10, April 20, April 30. It was investigated the influence on the yield capacity of tubers by the following fertilizers application namely: nitrogen, phosphorus and potassium, nitrogen species (ammonium nitrate and karbamid), and the efficiency of sulfur-acid magnesium and micro fertilizers Intermag was studied as well. The experiment included 10 variants: 1. No $P_{0}$ $\mathrm{K}_{0}$ - control, 2. $\mathrm{N}_{100} \mathrm{P}_{50} \mathrm{~K}_{120}$, 3. $\mathrm{N}_{150} \mathrm{P}_{75} \mathrm{~K}_{180}$, 4. $\mathrm{N}_{200} \mathrm{P}_{100} \mathrm{~K}_{240} \mathrm{~N}$-am. nitrate $\left(\mathrm{N}_{200}\right)$, 5. $\mathrm{N}_{200} \mathrm{P}_{100} \mathrm{~K}_{240}$ - N- karbamid (urea) $\left(\mathrm{N}_{200}\right)$, 6. $\mathrm{N}_{200} \mathrm{P}_{100} \mathrm{~K}_{240}$-am. nitrate $\left(\mathrm{N}_{133}\right)+$ karbamid (urea) $\left(\mathrm{N}_{67}\right)$, 7. $\mathrm{N}_{200} \mathrm{P}_{100} \mathrm{~K}_{240}$ - am.nitrate $\left(\mathrm{N}_{100}\right)+$ karbamid ( $\left.\mathrm{N}_{100}\right)$, 8. $\mathrm{N}_{200} \mathrm{P}_{100} \mathrm{~K}_{240}$ - am. nitrate $\left(\mathrm{N}_{67}\right)+$ karbamid ( urea) $\left(\mathrm{N}_{133}\right)$, 9. $\mathrm{N}_{200} \mathrm{P}_{100} \mathrm{~K}_{240}$-am. nitrate ( $\left.\mathrm{N}_{67}\right)$ + karbamid ( urea) $\left(\mathrm{N}_{133}\right)+\mathrm{MgSO}_{4}(5 \%), 10 . \mathrm{N}_{200} \mathrm{P}_{100} \mathrm{~K}_{240}$ - am.selitra $\left(\mathrm{N}_{67}\right)+$ karbamid ( urea) $\left(\mathrm{N}_{133}\right)+\mathrm{MgSO}_{4}$ $(5 \%)+$ Intermag microfertilizers. The area of leaf surface of sugar beet plants, photosynthetic potential of 
sowings was determined by the method of A.A. Nychyporovycha. Pure productivity of photosynthesis was calculated by the formula Kidda, Westa, Brihhsona:

Results. In our studies the leaf surface area was the lowest in the phase of closing leaves in rows. It should be noted that it had changed under the influence of sowing terms a little bit. This is primarily due to the fact that leaf area measurements were carried out at the appearance of the respective phases, which, depending on sowing terms falling on different dates. Thus, in the phase of closing leaves in rows the leaf surface area was small and ranged about - 5,3-5,8 thousand $\mathrm{m}^{2} /$ ha (Table 1 ). It has grown significantly in the phase of closing leaves between rows $\left(24,0-24,7\right.$ thousand $\left.\mathrm{m}^{2} / \mathrm{ha}\right)$, but too little has changed under the influence of sowing terms. During the intensive growth the leaf surface area was the highest $(49,3-53,7$ thousand $\mathrm{m}^{2} / \mathrm{ha}$ ), while during the harvesting this figure decreased up to $41,7-43,2$ thousands $\mathrm{m}^{2} / \mathrm{ha}$.

Calculations conducted on August 10, with reference to the date but not to the growth phase showed that the leaf surface is higher on the variants with early sowing terms. During the sowing on March 20 it was 53.7 thousand $\mathrm{m}^{2} / \mathrm{ha}$ and during the sowing on April 30 it decreased to 49.3 thousand $\mathrm{m}^{2} / \mathrm{ha}$. At the time of harvesting we observed the opposite data: the leaf area was smaller during the sowing on March 20 (41.7 thousand $\mathrm{m}^{2} / \mathrm{ha}$ ) and remained higher during late sowing. Much greater influence on the leaf surface area of sugar beets had fertilizers. This was

1. The leaf surface area of Carlton hybrid depending on the term of sowing, thous. $\mathrm{m}^{2} / \mathrm{ha}^{2}$

\begin{tabular}{|l|l|l|l|l|}
\hline Terms of Sowing & $\begin{array}{l}\text { Closing leaves in } \\
\text { rows }\end{array}$ & $\begin{array}{l}\text { Closing leaves } \\
\text { between rows }\end{array}$ & $\begin{array}{l}\text { Intensive growth, 10. } \\
08\end{array}$ & $\begin{array}{l}\text { Harvesting, } \\
01.10\end{array}$ \\
\hline 20 March & 5,8 & 24,7 & 53,7 & 41,7 \\
\hline 1 April & 5,7 & 24,6 & 50,8 & 42,5 \\
\hline 10 April & 5,4 & 24,5 & 49,4 & 43,0 \\
\hline 20 April & 5,3 & 24,1 & 49,7 & 43,2 \\
\hline 30 April & 5,4 & 24,0 & 49,3 & 43,1 \\
\hline
\end{tabular}

observed in other experiments too. So according to the data [5], the area of leaf surface on the variant without fertilizers counted 23.9 thousand $\mathrm{m}^{2}$, but during fertilizers application of $\mathrm{N}_{210} \mathrm{P}_{270} \mathrm{~K}_{255}$ it increased up to 49.6 thousand $\mathrm{m}^{2}$. In the phase of closing leaves in rows the greater leaf area ( 6.8 thousand $\mathrm{m}^{2} / \mathrm{ha}$ ) was on the fourth variant with ammonium nitrate application due to easily accessible content of nitrogen. On the control without fertilizers, it decreased to 4.1 thousand $\mathrm{m}^{2} /$ ha (Table. 2).

2. The leaf surface area of Carlton hybrid depending on fertilization, thous. $\mathrm{m}^{2} / \mathrm{ha}$.

\begin{tabular}{|c|c|c|c|c|}
\hline 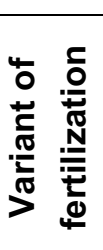 & $\begin{array}{l}\text { Closing leaves in } \\
\text { rows, } 01.06\end{array}$ & $\begin{array}{c}\text { Closing leaves } \\
\text { between rows, } \\
20.06\end{array}$ & $\begin{array}{c}\text { Intensive growth, } \\
10.08\end{array}$ & Harvesting 01.10 \\
\hline 1 & 4,1 & 12,4 & 22,4 & 18,5 \\
\hline 2 & 5,0 & 20,7 & 30,5 & 26,4 \\
\hline 3 & 5,9 & 24,9 & 35,5 & 31,0 \\
\hline 4 & 6,8 & 28,8 & 43,8 & 36,7 \\
\hline 5 & 5,0 & 23,3 & 40,5 & 38,8 \\
\hline 6 & 6,5 & 26,5 & 42,9 & 36,0 \\
\hline 7 & 6,1 & 25,8 & 41,7 & 36,5 \\
\hline 8 & 5,4 & 24,5 & 42,0 & 37,1 \\
\hline 9 & 5,3 & 25,0 & 45,1 & 39,7 \\
\hline 10 & 5,3 & 24,8 & 48,8 & 40,8 \\
\hline
\end{tabular}

In the phase of closing leaves between rows the leaf surface was developed intensively on the fourth variant, where it accounted about 28.8 thousand $\mathrm{m}^{2} / \mathrm{ha}$. 
The highest leaf area was on August 10, where, depending on the variant of researches it ranged within $22,4-48,8$ thousand $\mathrm{m}^{2} / \mathrm{ha}$. On the control without fertilizers it accounted 22.4 thousands $\mathrm{m}^{2} / \mathrm{ha}$, on the background of $N_{100} R_{50} K_{120}$ it increases up to 30.5 thousand $\mathrm{m}^{2} / \mathrm{ha}$, and on the background of $\mathrm{N}_{150} \mathrm{R}_{75} \mathrm{~K}_{180}$ it is increased up to 35.5 thousand $\mathrm{m}^{2} / \mathrm{ha}$ and on the variants with the application of $\mathrm{N}_{200} \mathrm{P}_{100} \mathrm{~K}_{240}$ it is within 40,5 48,8 thousand $\mathrm{m}^{2} / \mathrm{ha}$. It should be noted that on the background of $\mathrm{N}_{200} \mathrm{P}_{100} \mathrm{~K}_{240}$ better development of leaf apparatus is provided by ammonia nitrate. When using karbamid (urea) this index is decreased but the difference is not as great as in the previous phase. It should be noted that a significant influence on the leaf surface formation had magnesium and sulfur (45.1 thousand $\mathrm{m}^{2} / \mathrm{ha}$ ) and microfertilizers (48.8 thousand $\mathrm{m}^{2} / \mathrm{ha}$ ). During the tubers harvesting the leaf surface was decreased but in spite of it remains sufficient to continue accumulation of asymilyantives in the plant. At the end of the vegetation period more leaf area (38.8 thousand $\mathrm{m}^{2} / \mathrm{ha}$.) was on the variant with the karbamid (urea) application . It was observed also a significant effect of magnesium, sulfur and microfertilizers. Other researches noted that microfertilizers influenced on the increase of assimilation leaf surface of sugar beets positively [3]. As can be seen from the table. 3, photosynthetic potential in our studies was high and according to A.A.Nychyporovych gradation it can be refered to excellent ones. The increase of photosynthetic potential can be explained by the increase of leaf surface area due to the high rates of fertilizers application namely $\left(\mathrm{N}_{200} \mathrm{P}_{100} \mathrm{~K}_{240}\right)$.

\section{Indices of photosynthetic activity of sugar beets of Carlton hybrid depending on sowing terms.}

\begin{tabular}{|c|c|c|c|}
\hline $\begin{array}{l}\text { Sowing } \\
\text { terms }\end{array}$ & $\begin{array}{l}\text { Photosynthetic- } \\
\text { potential, mln.m² } \\
\text { days/ha }\end{array}$ & $\begin{array}{l}\text { Mass of dry matter of } \\
\text { plants for a period of } \\
\text { closing leaves in rows } \\
\text { before harvesting } \mathrm{g} / \mathrm{m}^{2}\end{array}$ & $\begin{array}{l}\text { Pure productivity of } \\
\text { photosynthesis, } g \text { of dry } \\
\text { matter } / \mathrm{m}^{2} \text { of leaf surface per day }\end{array}$ \\
\hline 20.03 & 5,08 & 2380 & 8,01 \\
\hline 01.04 & 4,92 & 2420 & 8,04 \\
\hline 10.04 & 4,67 & 2420 & 8,00 \\
\hline 20.04 & 4,49 & 2320 & 7,66 \\
\hline 30.04 & 4,36 & 2280 & 7,52 \\
\hline
\end{tabular}

Besides, during the researches were favourable hydrothermal conditions in the spring, which provided early intensive development of leaf mass (closing of leaves took place early on June 7-19) and they increased the duration of photosynthetic activity of well developed plants . Late sowings resulted into consistent reduction of photosynthetic potential due to the reducing of the length of active photosynthesis. Thus, on the variant with the sowing on March 20 it accounted about 5.08 million $\mathrm{m}^{2}$ days/ha, and during the sowing on April 30 - 4.36 million $\mathrm{m}^{2}$ days/ha, or reduced by 0.72 million $\mathrm{m}^{2}$ days/ha.

The mass of dry matter for the period from closing leaves in rows before harvesting was higher in variants with early terms of sowing, which it was $2380-2420 \mathrm{~g} / \mathrm{m}^{2}$. In our experiments the pure productivity of photosynthesis was the highest during the sowing on April $1-8.04 \mathrm{~g}$ of dry matter $/ \mathrm{m}^{2}$ of leaf surface per day (Table. 3). The pure productivity of photosynthesis was decreased during late sowing terms, namely from April 20 - to $7.66 \mathrm{~g}$ and April 30 - up to $7,52 \mathrm{~g}$ of dry matter $/ \mathrm{m}^{2}$ of leaf surface per day. Between sowings terms and other indices of photosynthetic activity was revealed a strong reverse connection, which for sowings terms and photosynthetic potential was $r=-0,99$, sowing terms and mass of dry matter was $r=-$ 0,76 , sowing terms and pure productivity of photosynthesis was $r=-0.90$. Researches of the effects of fertilization established that photosynthetic potential increases with the improving of nourishment conditions. On the control without fertilizers rates it accounts $2.12 \mathrm{mln} \cdot \mathrm{m}^{2}$ days/ha (Table. 4). With the increasing of fertilizers rates up to $\mathrm{N}_{100} \mathrm{P}_{50} \mathrm{~K}_{120}$ it increases to $3.14 \mathrm{mln} \cdot \mathrm{m}^{2}$ days/ha, on the background of $\mathrm{N}_{150} \mathrm{P}_{75} \mathrm{~K}_{180}$ is increased to $3.77 \mathrm{mln} . \mathrm{m}^{2}$ days/ha and on the variants with the application of $\mathrm{N}_{200} \mathrm{P}_{100} \mathrm{~K}_{240}$ it is within 4.16 $4.82 \mathrm{mln} \cdot \mathrm{m}^{2}$ days/ha. The highest photosynthetic potential (4.82 mln. $\mathrm{m}^{2}$ days/ha) was on the variant with the application of magnesium, sulfur and microelements. The mass of dry matter during the period of closing leaves in rows before the harvesting ranged within $1177-2432 \mathrm{~g} / \mathrm{m}^{2}$. On the control without fertilizers, this index is the lowest and accounts $1177 \mathrm{~g}$ and naturally it is increased with the application of the increased rates of fertilizers . Comparison of the fourth and fifth variants with the application of $\mathrm{N}_{200} \mathrm{P}_{100} \mathrm{~K}_{240}$ shows that 
photosynthetic potential was higher (4.53 mln. $\mathrm{m}^{2}$ days/ha) during the application of nitrogen ammonium nitrate. The mass of dry matter, by contrast, was higher $\left(2224 \mathrm{~g} / \mathrm{m}^{2}\right)$ on the variant with the application of karbamid ( urea). The highest mass of dry matter $\left(2432 \mathrm{~g} / \mathrm{m}^{2}\right)$ was on the variant with the application of magnesium, sulfur and microelements.

Index of pure productivity of photosynthesis was changed in the experiment with fertilizers within 7,75$8,81 \mathrm{~g}$ of dry matter $/ \mathrm{m}^{2}$ of leaf surface per day (Table. 4). Moreover, on the control without fertilizers pure productivity of photosynthesis was higher than on the fourth variant, with the application of $\mathrm{N}_{200} \mathrm{P}_{100} \mathrm{~K}_{240}$ respectively 8.02 and $7.75 \mathrm{~g}$ of dry matter $/ \mathrm{m}^{2}$ of leaf surface per day. This can be explained by a significant increase of leaf surface area on higher backgrounds.

4. Indices of photosynthetic activity of Carlton hybrid of sugar beet depending on the variant of fertilization.

\begin{tabular}{|l|l|l|l|}
\hline $\begin{array}{l}\text { Variant of } \\
\text { fertilization }\end{array}$ & $\begin{array}{l}\text { Photosynthetic } \\
\text { potential,min.m2 } \\
\text { days/ha }\end{array}$ & $\begin{array}{l}\text { Mass of dry matter of } \\
\text { plants for a period of } \\
\text { closing leaves in rows } \\
\text { before harvesting } \mathbf{g} / \mathbf{m}^{2}\end{array}$ & $\begin{array}{l}\text { Pure productivity of } \\
\text { photosynthesis, g of dry } \\
\text { matter/m } \mathbf{m}^{2} \text { of leaf surface per day }\end{array}$ \\
\hline 1 & 2.12 & 1177 & 8,02 \\
\hline 2 & 3,14 & 1586 & 8,09 \\
\hline 3 & 3,77 & 1867 & 8,08 \\
\hline 4 & 4,53 & 2068 & 7,75 \\
\hline 5 & 4,16 & 2224 & 8,12 \\
\hline 6 & 4,38 & 2196 & 8,25 \\
\hline 7 & 4,30 & 2265 & 8,51 \\
\hline 8 & 4,28 & 2344 & 8,81 \\
\hline 9 & 4,56 & 2390 & 8,51 \\
\hline 10 & 4,82 & 2432 & 8,44 \\
\hline
\end{tabular}

Correlation-regressive analysis of connections between fertilization and indices of photosynthetic activity shows a different character and strength of connections. Thus, between fertilization and photosynthetic potential was found the back medium connection $(r=-0,51)$, between fertilization and mass of dry matterdirect strong connection $(r=0,91)$, between fertilization and pure productivity of photosynthesis - direct strong connection $(r=0,76)$.

\section{Conclusions.}

Leaf surface area of sugar beets was the highest in the phase of intensive growth of plants. It was changed under the influence of sowing terms a little bit, but under the influence of fertilizers it was increased twice.

The pure productivity of photosynthesis was increased to $8,01-8,04 \mathrm{~g}$ of dry matter $/ \mathrm{m}^{2}$ of leaf surface per day during the early terms of sowing in the period from March 20 to April 10. The increasing of the rates of fertilizers application from $\mathrm{N}_{0} \mathrm{R}_{0} \mathrm{~K}_{0}$ to $\mathrm{N}_{200} \mathrm{R}_{100} \mathrm{~K}_{240}$ led to the increasing of photosynthetic potential from 2.12 $\mathrm{mln} \cdot \mathrm{m}^{2}$ days/ha to $4.82 \mathrm{mln} \cdot \mathrm{m}^{2}$ days/ha. But the mass of dry matter - from 1177 to $2432 \mathrm{~g} / \mathrm{m}^{2}$. The pure productivity of photosynthesis was less dependent on the level of fertilization and it was in the range of 7.75 $8.81 \mathrm{~g}$ of dry matter $/ \mathrm{m}^{2}$ of leaf surface per day.

\section{Bibliography}

1. Daskin V.Yu. Formirovaniie kachestva urozhaya pri vnyesienii Intermag Profi Svekla I Intermag element Bor/V.YU. Daskin, O.I. Antonova//Sakharnaya svekla.- 2013,-N 4,-S. 24-26.

2. Zaryshnyak A.S. Produktyvnist tsukrovykh buryakiv zalezhno vid sposobiv vnesennya mikrodobryv/A.S. Zaryshnyak//Tsukrovi buryaky.-2013.-№ 1.- C.12-13.

3. Karpuk L.M. Vplyv pozakorenevogo pidzhyvlennya mikrodobryvamy na pokaznyky fotosyntetychnoi produktyvnosti tsukrovykh buryakiv/L.M. Karpuk//Agrobiologiya: Zbirnyk naukovykh prats/Bilotserkiv. nats.agrar. un-t.- Bila Tserkva, 2014.- Vyp. 1(109).-S.41-44. 
4. Karpuk L.M. Fotosyntetychna produktyvnist tsukrovykh buryakiv zalezhno vid gustoty nasadzhennya roslyn/L.M. Karpuk//Agrobiologiya: Zbirnyk naukovykh prats/Bilotserkiv. nats. agrar. in-t.- Bila Tserkva, 2013Vyp.- 10 (100).- S.13-18.

5. Marchuk I.U. Vplyv dobryv na urozhai I vmist sakharozy v koreneplodakh buryakiv tsukrovykh $v$ riznykh lankakh sivozminy/I.Y. Marchuk, V.M. Kozak, L.V. Panchuk//Naykovi pratsi Instytutu bioenergetychnykh kultur I tsukrovykh buryakiv: zb. nauk. prats/In-t bioenerget. kultur I tsukr. buryakiv, Nats. akad. agrar. nauk Ukrainy.-K: FOP Korzun D.Yu., 2013.- Vyp. 17.- Tom II.- s.67-72.

6. Nychyporovych A.A. Teoretycheskie osnovy povyshenia produktyvnosti rasteniy.- M.: VINITI, 1977.$134 \mathrm{~s}$.

7. Nychyporovych A.A. Fotosyntez I voprosy intensyfikatsii selskogo khoziaistva/A.A. Nychyporovych.M.: Nayka, 1965.-48c.

8. Systemy suchasnykh intensyvnykh tekhnologiy [V.D. Palamarchuk, I.S. Polishchuk, L.M. Yermakova, S.M. Kalenska] - 2-ge vyd. Vypr.. ta dopovn.- Vinnytsia: FOP Rogalska I.O., 2012.- 370s.

9. Buraki cukrowe/S. Barnas, A. Szreder, M. Nowakowski.- Warszawa: Agro Serwis, Biznes Press, 2003.- 80c.

10. Grzeskowiak A., Jakubowski W. System nawozenia "Police".- Police: Agencia Reklamowa DCS, 2004.- 80c. 